\title{
Detection of autoantibodies to citrullinated BiP in rheumatoid arthritis patients and pro-inflammatory role of citrullinated BiP in collagen-induced arthritis
}

Hirofumi Shoda', Keishi Fujio ${ }^{1 *}$, Mihoko Shibuya' ${ }^{1}$, Tomohisa Okamura', Shuji Sumitomo ${ }^{1}$, Akiko Okamoto', Tetsuji Sawada² and Kazuhiko Yamamoto ${ }^{1}$

\begin{abstract}
Introduction: Anti-citrullinated protein/peptide antibodies (ACPAs) are highly specific to rheumatoid arthritis (RA) patients and are thought to have a close relationship with the pathogenesis of arthritis. Several proteins, including fibrinogen, vimentin, and alpha-enolase, were reported as ACPA-target antigens, and their importance in RA pathogenesis was widely proposed. We identified citrullinated immunoglobulin binding protein (citBiP) as another ACPA target in RA patients and examined its pro-inflammatory role in arthritis.

Methods: We measured the levels of anti-citBiP, anti-BiP, and anti-cyclic citrullinated peptide (CCP) antibodies in the serum of RA patients $(n=100)$, systemic lupus erythematosus (SLE) patients $(n=60)$, and healthy controls $(n=$ 30) using ELISA and immunoblotting. Epitope mapping was performed using 27 citBiP-derived peptides. In the mouse study, after DBA/1J mice were immunized with BiP or citBiP, serum titers of ACPAs were measured by ELISA and immunohistochemistry. The development of collagen-induced arthritis (CIA) was observed in BiP- or citBiP-preimmunized mice.

Results: The serum levels of anti-BiP and anti-citBiP antibodies were significantly increased in RA patients, although only anti-BiP antibodies were slightly increased in SLE patients. Interestingly, anti-citBiP antibody levels were higher than anti-BiP antibody levels in 72\% of RA patients, whereas no significant increase in anti-citBiP antibody levels was detected in SLE patients and healthy controls. The serum levels of anti-CCP antibodies were correlated with those of anti-citBiP antibodies in RA patients $\left(R^{2}=0.41\right)$. Several citrulline residues of citBiP were determined to be major epitopes of anti-citBiP antibodies, one of which showed cross-reactivity with CCP. Immunization of DBA/1J mice with citBiP induced several kinds of ACPAs, including anti-CCP and anti-citrullinated fibrinogen antibodies. Pre-immunization with citBiP exacerbated CIA, and anti-CCP antibody levels were increased in citBiP-pre-immunized CIA mice.
\end{abstract}

Conclusions: CitBiP is a newly described ACPA target that may play a pro-inflammatory role in arthritis.

\section{Introduction}

Rheumatoid arthritis (RA) is described as a chronic inflammation of multiple joints with destructive processes and is characterized by sustained synovitis, pannus proliferation, and destruction of the cartilage and

\footnotetext{
* Correspondence: kfujio-tky@umin.ac.jp

'Department of Allergy and Rheumatology, Graduate School of Medicine,

the University of Tokyo, 7-3-1 Hongo, Bunkyo-ku, Tokyo, Japan

Full list of author information is available at the end of the article
}

bones. Many inflammatory processes participate in the pathogenesis of RA, and autoimmune responses are considered fundamental abnormalities in RA [1]. Autoantibodies such as rheumatoid factor (RF) are detected in the serum and synovial fluid of RA patients. Although the sensitivity of RF in diagnosing RA is $30 \%-70 \%$ in early cases and $80 \%-85 \%$ in progressive cases, the specificity of RF is $\sim 40 \%$ [2]. Recently, anti-citrullinated protein/peptide antibodies (ACPAs) were reported to be 
highly specific in the diagnosis of RA $[3,4]$. Detection systems for anti-cyclic citrullinated peptide (CCP) antibodies have been improved, and the sensitivity and specificity of anti-CCP antibodies in the diagnosis of RA are $60 \%-80 \%$ and $95 \%-98 \%$, respectively [5,6]. Importantly, anti-CCP antibodies are detected several years before joint inflammation is observed $[7,8]$. Due to the high specificity of ACPAs in RA, their role in the pathogenesis of RA has become the focus of active investigation.

ACPAs were first described as anti-rat esophageal antibodies, and Girbal-Neuhauser et al. discovered that citrullinated filaggrin was a target antigen of those antibodies [3]. Although citrullinated filaggrin is not present in the inflammatory synovium of RA patients, several citrullinated auto-antigens, including citrullinated fibrinogen, vimentin, type II collagen, and alpha-enolase, have been reported as target antigens of ACPAs in the synovia of RA patients [9-14]. In one hypothesis for the pathogenesis of RA, ACPAs bind to these citrullinated auto-antigens in the synovial tissues and form immune complexes that induce inflammatory processes [15]. Once synovial inflammation occurs, apoptosis and protein citrullination are induced. The continuous production of ACPAs and immune complexes results in sustained joint inflammation [16]. Indeed, serum C1qbinding immune complexes isolated from RA patients contained citrullinated fibrinogen [17], and immunization of citrullinated fibrinogen induced inflammatory arthritis in HLA-DR4 transgenic mice [18]. However, the mechanisms by which ACPAs develop and synovial proteins are citrullinated in humans remain unclear. Furthermore, the causes of RA remain unclear; it is suggested that genetic and environmental factors could cause RA, and several genetic risk factors have recently been determined. Importantly, single nucleotide polymorphisms in the peptidylarginine deaminase, type IV (PADI4) gene, which encodes a key enzyme for protein citrullination, are associated with RA susceptibility [19]. Therefore, auto-antigen citrullination and ACPA development are considered as important steps in the pathogenesis of RA.

The presence of serum anti-immunoglobulin binding protein (BiP) antibodies has been reported in RA sera, and anti-BiP antibodies showed similar sensitivity and specificity as RF $[20,21]$. BiP is a member of the heat shock protein 70 family and is expressed in the endoplasmic reticulum. It functions as a molecular chaperone and can bind to many proteins. BiP concentrations are elevated in the synovial fluid of RA patients [21], and BiP-responsive $\mathrm{T}$ cells are also detected in RA patients [22]. Here, we described the detection of anti-citrullinated $\mathrm{BiP}$ (citBiP) antibodies in the serum of $\mathrm{RA}$ patients. An epitope mapping study revealed that several citrulline residues were recognized by anti-citBiP antibodies. In a mouse study, we observed that immunization with citBiP induced ACPAs, including anti-CCP and anti-citrullinated fibrinogen antibodies. In addition, collagen-induced arthritis (CIA) was exacerbated by preimmunization with citBiP. Therefore, we concluded that citBiP is a newly determined target of ACPAs and that it is closely related to the pathogenesis of inflammatory arthritis.

\section{Materials and methods \\ Patients}

Serum samples were obtained from 100 RA patients, 60 systemic lupus erythematosus (SLE) patients, and 30 healthy volunteers. All of the RA patients fulfilled the 1987 and 2010 American College of Rheumatology criteria for RA [23,24]. SLE diagnosis was made according to the diagnostic criteria of the American College of Rheumatology [25,26]. Written informed consent was obtained before blood samples were taken. This study was approved by the ethics committee of Tokyo University Hospital.

\section{Mice}

DBA/1J female mice (age: 6-8 weeks) were obtained from SLC Japan (Shizuoka, Japan). All animal experiments were conducted in accordance with institutional and national guidelines.

\section{Antigens and peptides}

A full-length fragment of mouse BiP cDNA (GenBank: AJ002387) was subcloned, and the plasmid vector, which contained a mouse BiP cDNA sequence with a $\mathrm{His}^{6}$-tag at its N-terminal, was prepared using a Champion pET Directional TOPO Expressing Kit (K100-01; Invitrogen, Carlsbad, CA, USA). The vector was transduced into BL21 Star One Shot Chemically Competent Escherichia coli (Invitrogen) by using a heat shock procedure. The transformed BL21 E. coli were incubated in LB medium with ampicillin $(100 \mu \mathrm{g} / \mathrm{mL})$. When the absorbance (O.D. $650 \mathrm{~nm}$ ) rose to $0.5,1 \mathrm{mM}$ of isopropylthio-beta-galactoside (Invitrogen) was added to the medium. After a $6 \mathrm{~h}$ incubation, the pellet was dissolved using the Fast Break Cell Lysis Reagent (Promega, Madison, WI, USA) and the lysate was purified using an NiNTA Fast Start Kit (QIAGEN, Valencia, CA, USA) according to the manufacturer's procedure. Mouse fibrinogen was purchased from Sigma-Aldrich (St. Louis, MO, USA). For endotoxin removal, purified proteins were passed through a Detoxi-Gel AffinityPak prepared column (Pierce, Rockford, IL, USA) according to the manufacturer's protocol.

For protein citrullination, $2 \mathrm{U}$ of rabbit PADI2 (Sigma-Aldrich) were added to $1 \mathrm{mg}$ of the protein in 
buffered medium (0.1 M Tris- $\mathrm{HCl}, 10 \mathrm{mM} \mathrm{CaCl} 2,5 \mathrm{mM}$ DTT) at $37^{\circ} \mathrm{C}$ for $2 \mathrm{~h}$. EDTA $(20 \mathrm{mM})$ was added to stop the reaction [15]. The samples were then passed through the Ni-NTA column to remove PADI2.

The peptides (Tables 1 and 2) were synthesized using NeoMPS (San Diego, CA, USA). Native BiP-derived

Table 1 Synthetic peptides derived from native human BiP protein

\begin{tabular}{|c|c|c|}
\hline Number & Amino acid sequences & Position \\
\hline $\mathrm{BiP} 1$ & EDKKEDVGTWGIDLGTTYS & $21-40$ \\
\hline $\mathrm{BiP} 2$ & GTTYSCVGVFKNGRVEIIAN & $36-55$ \\
\hline $\mathrm{BiP} 3$ & EIIANDQGNRITPSYVAFTP & $51-70$ \\
\hline Bip4 & VAFTPEGERLIGDAAKNQLT & $66-85$ \\
\hline Bip5 & KNQLTSNPENTVFDAKRLIG & $81-100$ \\
\hline BiP6 & KRLIGRTWNDPSVQQDIKFL & $96-115$ \\
\hline $\mathrm{BiP7}$ & DIKFLPFKWEKKTKPYIQV & $111-130$ \\
\hline Bip8 & PYIQVDIGGGQTKTFAPEEI & $126-145$ \\
\hline Bip9 & APEEISAMVLTKMKETAEAY & $141-160$ \\
\hline BiP10 & TAEAYLGKKVTHAVTVPAY & $156-175$ \\
\hline BiP11 & TVPAYFNDAQRQATKDAGTI & $171-190$ \\
\hline $\mathrm{BiP} 12$ & DAGTIAGLNVMRIIINEPTAA & $186-205$ \\
\hline $\mathrm{BiP} 13$ & EPTAAAIAYGLDKREGEKNI & $201-220$ \\
\hline $\mathrm{BiP} 14$ & GEKNILVFDLGGGTFDVSLL & $216-235$ \\
\hline BiP15 & DVSLLTIDNGVFEWATNGD & $231-250$ \\
\hline $\mathrm{BiP} 16$ & ATNGDTHLGGEDFDQRVMEH & $246-265$ \\
\hline BiP17 & RVMEHFIKLYKKKTGKDVRK & $261-280$ \\
\hline BiP18 & KDVRKDNRAVQKLRREVEKA & $276-295$ \\
\hline BiP19 & EVEKAKRALSSQHQARIEIE & $291-310$ \\
\hline $\mathrm{BiP} 20$ & RIEIESFYEGEDFSETLTRA & $306-325$ \\
\hline $\mathrm{BiP} 21$ & TLTRAKFEELNMDLFRSTMK & $321-340$ \\
\hline $\mathrm{BiP} 22$ & RSTMKPVQKVLEDSDLKKSD & $336-355$ \\
\hline $\mathrm{BiP} 23$ & LKKSDIDEIVLVGGSTRIPK & $351-370$ \\
\hline BiP24 & TRIPKIQQLVKEFFNGKEPS & $366-385$ \\
\hline $\mathrm{BiP} 25$ & GKEPSRGINPDEAVAYGAAV & $381-400$ \\
\hline BiP26 & YGAAVQAGVLSGDQDTGDLV & $396-415$ \\
\hline $\mathrm{BiP} 27$ & TGDLVLLDVCPLTLGIETVG & $411-430$ \\
\hline $\mathrm{BiP} 28$ & IETVGGVMTKLIPRNTWPT & $426-445$ \\
\hline $\mathrm{BiP} 29$ & TVPTKKSQIFSTASDNQPT & $441-460$ \\
\hline BiP30 & DNQPTVTIKVYEGERPLTKD & $456-475$ \\
\hline BiP31 & PLTKDNHLLGTFDLTGIPPA & $471-490$ \\
\hline BiP32 & GIPPAPRGVPQIEVTFEIDV & $486-505$ \\
\hline $\mathrm{BiP} 33$ & FEIDVNGILRVTAEDKGTGN & $501-520$ \\
\hline BiP34 & KGTGNKNKITITNDQNRLTP & $516-535$ \\
\hline $\mathrm{BiP} 35$ & NRLTPEEIERMVNDAEKFAE & $531-550$ \\
\hline $\mathrm{BiP} 36$ & EKFAEEDKKLKERIDTRNEL & $546-565$ \\
\hline BiP37 & TRNELESYAYSLKNQIGDKE & $561-580$ \\
\hline BiP38 & IGDKEKLGGKLSSEDKETME & $576-595$ \\
\hline $\mathrm{BiP} 39$ & KETMEKAVEEKIEWLESHQD & $591-610$ \\
\hline $\mathrm{BiP} 40$ & ESHQDADIEDFKAKKKELEE & $606-625$ \\
\hline $\mathrm{BiP} 41$ & KELEEIVQPIISKLYGSAGP & $621-640$ \\
\hline BiP42 & GSAGPPPTGEEDTAELHHHH & $636-655$ \\
\hline
\end{tabular}

$\mathrm{BiP}=$ immunoglobulin-binding protein.
Table 2 Synthetic peptides

\begin{tabular}{rll}
\hline Number & Amino acid sequences & Position \\
\hline 1 & YSCVGVFKNG(Cit)VEIIANDQG & $39-58$ \\
2 & VEIIANDQGN(Cit)ITPSYVAFT & $50-69$ \\
3 & SYVAFTPEGE(Cit)LIGDAAKNQ & $64-83$ \\
4 & NPENTVFDAK(Cit)LIGRTWNDP & $87-106$ \\
5 & TVFDAKRLIG(Cit)TWNDPSVQQ & $91-110$ \\
6 & TVPAYFNDAQ(Cit)QATKDAGTI & $171-190$ \\
7 & AGTIAGLNVM(Cit)IINEPTAAA & $187-206$ \\
8 & AAAIAYGLDK(Cit)EGEKNILVF & $204-223$ \\
9 & THLGGEDFG(Cit)VMEHFIKLY & $251-270$ \\
10 & LYKKKTGKDV(Cit)KDNRAVQKL & $269-288$ \\
11 & KTGKDVRKDN(Cit)AVQKLRREV & $273-292$ \\
12 & RKDNRAVQKL(Cit)REVEKAKRA & $279-298$ \\
13 & KDNRAVQKLR(Cit)EVEKAKRAL & $280-299$ \\
14 & KLRREVEKAK(Cit)ALSSQHQAR & $287-306$ \\
15 & AKRALSSQHQA(Cit)IEIESFFE & $295-314$ \\
16 & FEGEDFSETLT(Cit)AKFEELNM & $313-332$ \\
17 & AKFEELNMDLF(Cit)STMKPVQK & $325-344$ \\
18 & IDEIVLVGGST(Cit)IPKIQQLV & $356-375$ \\
19 & VKEFFNGKEPS(Cit)GINPDEAV & $375-394$ \\
20 & TVGGVMTKLIP(Cit)NTVPTKK & $428-447$ \\
21 & TVTIKVYEGE(Cit)PLTKDNHLL & $460-479$ \\
22 & FDLTGIPPAP(Cit)GVPQIEVTF & $482-501$ \\
23 & TFEIDVNGIL(Cit)VTAEDKGTG & $500-519$ \\
24 & NKITITNDQN(Cit)LTPEEIERM & $522-541$ \\
25 & QNRLTPEEIE(Cit)MVNDAEKFA & $530-549$ \\
26 & FAEEDKKLKE(Cit)IDTRNELES & $548-567$ \\
27 & EDKKLKERIDT(Cit)NELESYAYS & $551-570$ \\
$11 R$ & KTGKDVRKDNRAVQKLRREV & $273-292$ \\
$12 R$ & RKDNRAVQKLRREVEKAKRA & $279-298$ \\
$15 R$ & AKRALSSQHQARIEIESFFE & $295-306$ \\
$23 R$ & TFEIDVNGILRVTAEDKGTG & $500-519$ \\
\hline & & \\
\hline & & \\
\hline
\end{tabular}

Cit: citrulline residue.

peptides were also prepared that covered the entire human BiP sequence (GenBank: CAA61201) (Table 1). $\mathrm{BiP}$ includes 27 arginine residues that could be replaced by citrulline; therefore, we designed 27 synthesized peptides that each contained 1 citrulline residue (Table 2). In some experiments, we also prepared original peptides without citrullination. Peptide purity was $>80 \%$.

\section{Immunization of mice}

Murine BiP and citBiP were emulsified with an equal volume of complete Freund's adjuvant (CFA) (Chondrex, Redmond, WA, USA), and DBA/1J mice were immunized with $100 \mu \mathrm{g}$ of murine BiP or citBiP intradermally at the tail base. Spleen samples for culture were obtained at 14 days post-immunization and serum samples for antibody titer measurements were obtained at 28 days post-immunization. 


\section{ELISA}

The serum levels of the anti-CCP antibodies were measured using MESACUP FCCP200 (Axis-Shield Diagnostics Ltd., Dundee, UK). Anti-CCP antibodies in the human serum samples were measured according to the manufacturer's protocol. Goat anti-mouse IgG-alkaline phosphate (Chemicon, Temecula, CA, USA) was used at a 3000-fold dilution as the detection antibody for measuring mouse serum anti-CCP antibodies [15]. In the competitive assay, the indicated concentrations of citrullinated peptides were added to human anti-CCP antibody-positive standard serum samples (a mixture of serum from 18 ACPA-positive RA patients), the samples were incubated for $2 \mathrm{~h}$ at room temperature, and the anti-CCP antibody levels were then measured.

To detect antibodies to other proteins, $5 \mu \mathrm{g} / \mathrm{mL}$ of each antigen was dissolved in $0.1 \mathrm{M} \mathrm{NaHCO}_{3}$ and $100 \mu \mathrm{L}$ of each were plated in 96-well plates (Immuron4 Multiplate; Dynatech Laboratories, Chantilly, VA, USA) at $4^{\circ} \mathrm{C}$ for 16 h. After the plates were blocked using PBS containing 3\% skimmed milk and $0.5 \%$ Tween-20, $\times 100$ diluted samples were applied. Goat anti-human IgG-horseradish peroxidase (HRP) (Vector, Burlingame, CA, USA) or goat antimouse IgG-HRP antibodies (Zymed, South San Francisco, CA, USA) were used at a 5000 -fold dilution as detection antibodies and TMB solution (KPL, Gaithersburg, MD, USA) was used to develop the colors. An automatic microplate reader (Bio-Rad 550; Bio-Rad, Hercules, CA, USA) was used to measure optical density.

\section{Immunoblotting}

After $1 \mu \mathrm{g}$ BiP or citBiP was electrophoresed using sodium dodecyl sulfate-polyacrylamide gel electrophoresis, the samples were blotted to Hybond ECL (GE Healthcare). The membranes were blocked with PBS containing $10 \%$ skimmed milk at room temperature for $1 \mathrm{~h}$ and $\times 100$ diluted serum samples were then applied at $4^{\circ} \mathrm{C}$ for $16 \mathrm{~h}$. A goat anti-human IgG-HRP antibody was used at a 5000-fold dilution as the detection antibody. The membranes were treated with ECL reagent (GE Healthcare, Buckinghamshire, UK) and the film images were developed. A polyclonal rabbit anti-BiP antibody (Thermo Fisher Scientific, Rockford, IL, USA) was used at a 100-fold dilution as a positive control. A Senshu antibody (rabbit polyclonal anti-modified citrulline antibody; Upstate Biochemicals, Lake Placid, NY, USA) was used to detect the citrullinated antigens, and blotting was performed in accordance with the manufacturer's protocol [27]. Band density was quantified using NIH ImageJ software.

\section{Immunofluorescence assay}

Rat esophageal sections (SCIMEDX Corporation, Denville, NJ, USA) were used, and citrullinated filaggrin was detected according to the manufacturer's protocol. In short, mouse serum samples were treated at room temperature for $1 \mathrm{~h}$ and Alexa Fluor 488-conjugated goat anti-mouse IgG antibody (Invitrogen) was used as the detection antibody. The samples were observed under a fluorescent microscope [15].

\section{Collagen-induced arthritis}

CIA was induced as described previously [28]. In short, bovine type II collagen (Chondrex) was emulsified with an equal volume of CFA or incomplete Freund's adjuvant (IFA) (Chondrex). Fourteen days after immunization with $\mathrm{BiP}$ or citBiP, DBA/1J mice were immunized with $50 \mu \mathrm{g}$ bovine type II collagen intradermally at the tail base on day 14 with CFA and on day 35 with IFA. The arthritis score was determined by the degree of erythema, swelling, or ankylosis observed on each paw, as described elsewhere [29]. The mice were sacrificed at 50 days after the first CIA immunization. Tissue samples were embedded in paraffin wax after $10 \%$ formaldehyde fixation and decalcification. The sections were stained with hematoxylin and eosin. Synovial tissues were graded by mononuclear cell infiltration, pannus formation, and cartilage erosion, as described previously [30].

\section{Statistical analysis}

All values are expressed as the median. Differences were compared using the Mann-Whitney U test. Correlations between the levels of two antibodies were analyzed by the Spearman correlation coefficient. Graphpad Prism 5 was used for statistical analysis. $P$-values $<0.05$ were considered significant.

\section{Results}

\section{Anti-citBiP antibodies in the serum of RA patients}

We first measured the serum levels of anti-BiP and anticitBiP antibodies in RA patients, SLE patients, and healthy controls (Figure 1A). Among these patients, 95 RA patients and no SLE patients were positive for antiCCP antibodies. We chose SLE patients as disease controls because $\sim 30 \%$ of SLE patients are positive for antiBiP antibodies, while serum anti-CCP antibodies are detected in $<5 \%$ of SLE patients [31]. In RA patients, the levels of anti-BiP and anti-citBiP antibodies were significantly higher than those observed in SLE patients and healthy controls $(p<0.001)$. Immunoblotting analysis demonstrated higher serum concentrations of anticitBiP antibodies than anti-BiP antibodies in the serum of each anti-CCP antibody-positive RA patient (Figure 1B). Seventy-two percent of RA patients showed higher anti-citBiP antibody levels than anti-BiP antibody levels, whereas there was no significant difference in the serum titers of anti-BiP and anti-citBiP antibodies in the non- 


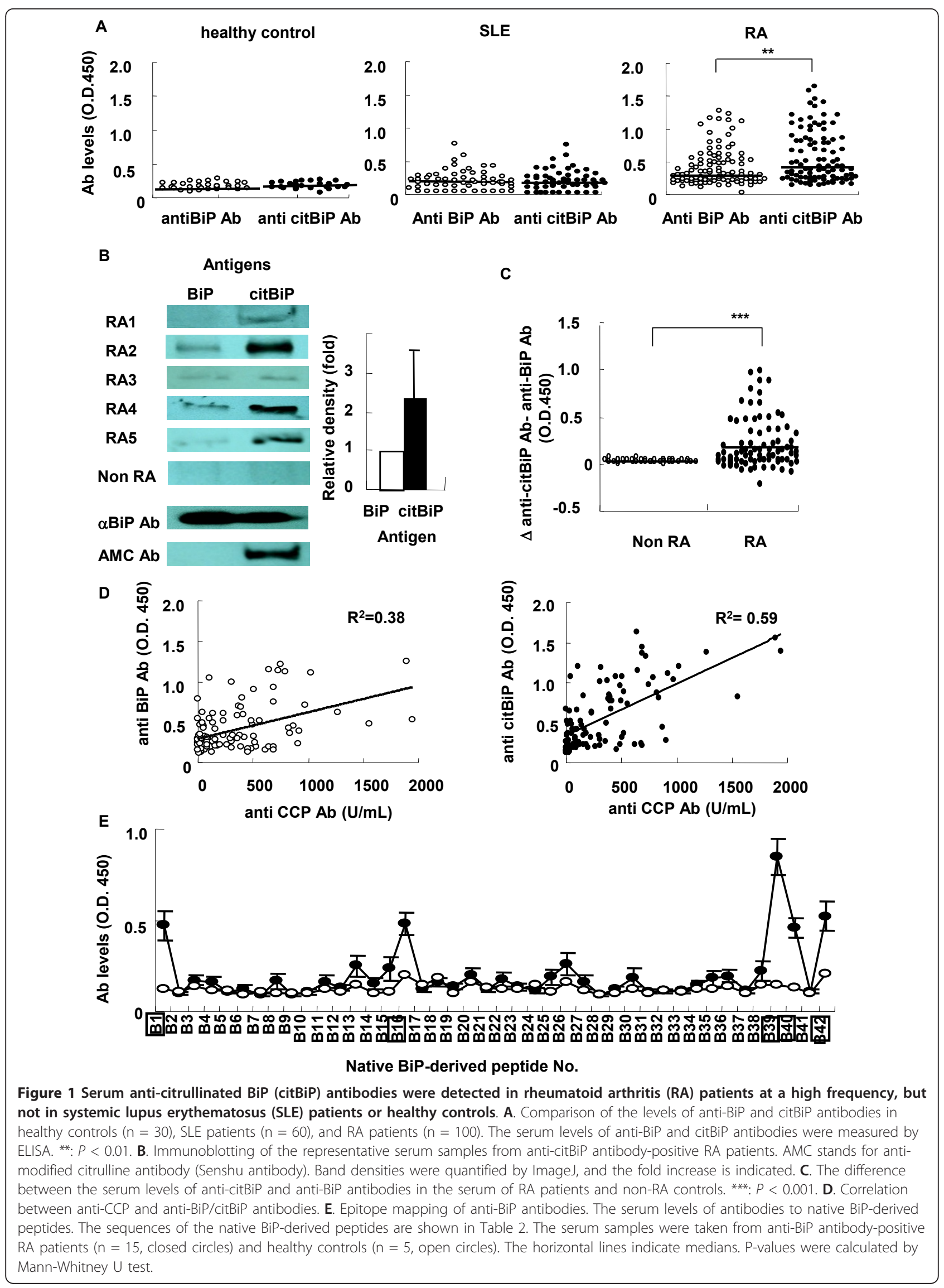


RA controls (Figure 1C). A previous report suggested that serum anti-BiP antibodies were detected in SLE patients [31]; in our study, the serum levels of anti-BiP and anti-citBiP antibodies in SLE patients were mildly increased in comparison with those in healthy controls $(p<0.05)$ (Figure 1A). However, in contrast to RA, there was no significant difference in the serum levels of anti-BiP and anti-citBiP antibodies in SLE patients (Figure $1 C$ ). In RA patients, the serum levels of anti-citBiP antibodies were strongly correlated with those of antiCCP antibodies $\left(R^{2}=0.59\right)$, whereas the levels of anti$\mathrm{BiP}$ antibodies were less correlated with those of antiCCP antibodies $\left(R^{2}=0.38\right)$ (Figure 1D). Therefore, the serum levels of anti-citBiP antibodies are higher than those of anti-BiP antibodies and have a clear association with anti-CCP antibodies in RA patients.

Because $\mathrm{BiP}$ is an immunoglobulin chaperon protein, there is the possibility that immunoglobulins bind to $\mathrm{BiP}$, independent of epitope recognition by the antigenbinding site. To confirm the existence of specific epitope recognition, epitope mapping was performed by using native human BiP-derived peptides. The mapping revealed that $\mathrm{BiP} 1\left(\mathrm{BiP}_{21-40}\right), \mathrm{BiP} 16\left(\mathrm{BiP}_{246-265}\right), \mathrm{BiP} 39$ ( $\left.\mathrm{BiP}_{591-610}\right), \mathrm{BiP} 40$ ( $\left.\mathrm{BiP}_{606-625}\right)$, and $\mathrm{BiP} 42\left(\mathrm{BiP}_{636-655}\right)$ were the epitopes recognized by the anti-BiP antibodies (Figure 1E). Most of these major epitopes were located in the $\mathrm{C}$ and $\mathrm{N}$ terminals. Therefore, anti-human BiP antibodies truly exist in the serum of RA patients.

\section{Determination of the citrullinated epitopes of anti-citBiP antibodies}

To identify the citrullinated epitopes of the anti-citBiP antibodies in RA, we prepared citrullinated peptides in which the arginine residues of the native BiP sequences were replaced with citrulline residues. Serum antibody levels to each of the citBiP-derived peptides were measured in RA patients with high anti-citBiP antibody levels $(n=18)$ and healthy controls $(n=5)$. The serum antibody levels were increased against several citrullinated peptides (Figure 2A). Four of the major citBiPderived epitopes were selected for further investigation, and the serum levels of the anti-native peptide antibodies and the anti-citrullinated peptide antibodies were compared (Figure 2B). The serum antibody levels to No. 12 (BiP 279-298 R289citrulline), 15 (BiP 295-314 R305citrulline), and 23 ( $\mathrm{BiP}_{500-519}$ R510citrulline) citrullinated peptides were significantly increased compared with those of the native peptides in RA patients. Thus, these citrullinated residues were thought to be important residues for autoantibody recognition in RA. Thus, the positions of the major citrullinated epitopes $\left(\mathrm{BiP}_{279}\right.$ 298, $\mathrm{BiP}_{295-314}$, and $\left.\mathrm{BiP}_{500-519}\right)$ were different from the major epitopes of the native $\mathrm{BiP}$ protein $\left(\mathrm{BiP}_{21-40}\right.$, $\mathrm{BiP}_{246-265}, \mathrm{BiP}_{591-610}, \mathrm{BiP}_{604-625}$, and $\left.\mathrm{BiP}_{636-655}\right)$. In particular, the No. 23 citrullinated peptide inhibited serum antibody binding to CCP, whereas the No. 22 peptide did not (Figure 2C). No. 12 and 15 citrullinated peptides did not bind to CCP either (data not shown). Therefore, we identified several citrullinated anti-citBiP antibody epitopes, one of which showed a clear crossreaction with $\mathrm{CCP}$.

\section{Induction of ACPAs in citBiP-immunized mice}

We then examined whether active immunization with citBiP could induce ACPAs in a mouse model. DBA/1J mice were immunized with $\mathrm{BiP}$ or citBiP and serum samples were obtained after 28 days. Anti-CCP antibodies were detected in the serum samples of citBiPimmunized mice (Figure 3A). Although BiP immunization also induced the development of anti-CCP antibodies, the anti-CCP antibody levels were relatively low. Because Vossenaar et al. pointed out that some mouse models of inflammatory arthritis developed false-positive anti-CCP antibodies [32], we verified the presence of ACPAs using different methods. The serum levels of anti-citrullinated fibrinogen antibodies were only detected in the sera of citBiP-immunized mice (Figure 3B). We stained rat esophageal horny layer containing citrullinated filaggrin with sera from citBiP-immunized mice (Figure 3C). Therefore, we confirmed that citBiP immunization not only induced anti-citBiP antibodies but also induced other ACPAs.

\section{Exacerbation of CIA by pre-immunization with citBiP}

Finally, we tested the pro-inflammatory effects of citBiP in the CIA mouse model. Similar to the findings in RA, CIA mouse sera contained anti-BiP and anti-citBiP antibodies (Figure 4A). The serum levels of anti-citBiP antibodies were higher than those of anti-BiP antibodies. Since the development of ACPAs precedes the onset of $\mathrm{RA}$, some immune responses to citrullinated antigens are hypothesized to occur before RA becomes clinically obvious. We assessed this hypothesis by pre-immunizing mice with citBiP before inducing CIA, and determined whether the immune responses to citBiP were associated with the enhancement of inflammatory arthritis. Fourteen days after $\mathrm{BiP}$ or citBiP immunization, the mice were immunized with bovine type II collagen to induce arthritis. Joint inflammation developed sooner and was significantly exacerbated in the citBiP-pre-immunized mouse group as compared to the control group (Figure 4B and Additional file 1). BiP-pre-immunized mice did not develop severe arthritis. There was a significant increase in the histological scores of the citBiP-preimmunized mouse group (Figure $4 \mathrm{C}$ ). The serum levels of anti-CCP antibodies were also significantly elevated in the citBiP-pre-immunized mice (Figure 4D). Therefore, citBiP immunization exacerbated inflammatory 


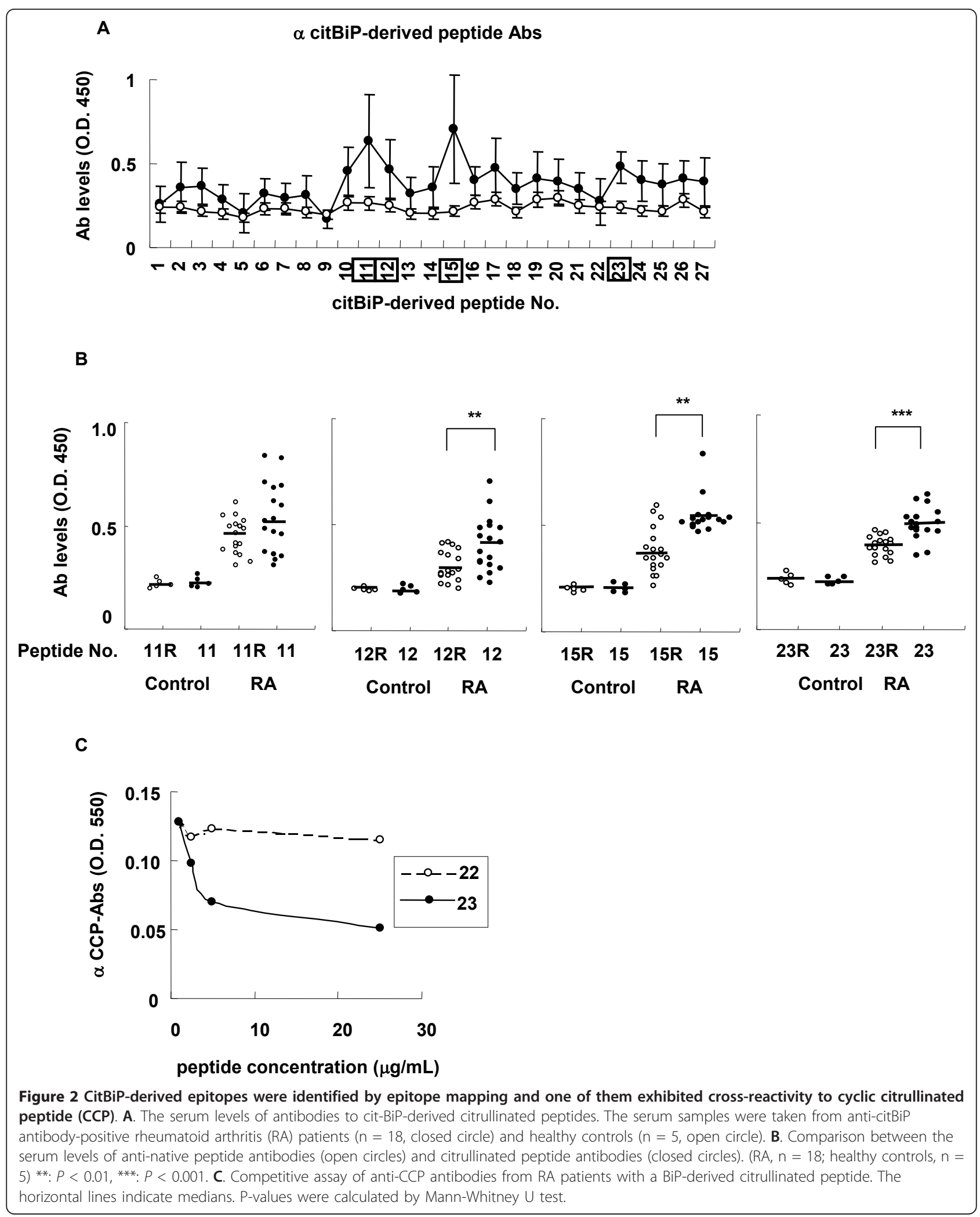




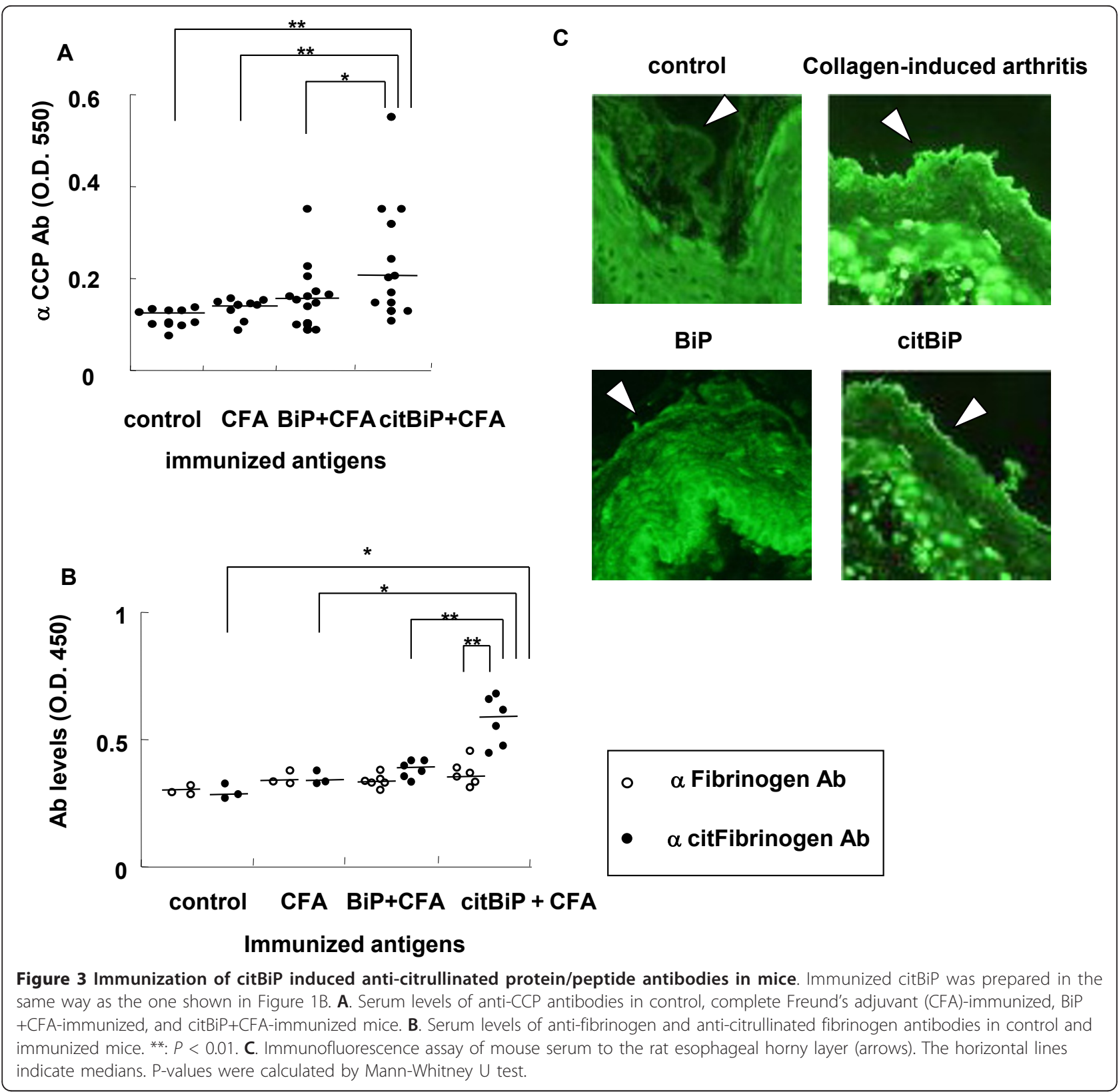

arthritis in mice, whereas BiP immunization had no significant effect on CIA.

\section{Discussion}

$\mathrm{BiP}$ is a molecular chaperone that is expressed in the endoplasmic reticulum and a known RA auto-antigen. $\mathrm{BiP}$ is overexpressed in the synovial fluids of RA patients, and anti-BiP antibodies develop in $60 \%$ of RA patients $[20,21] . \mathrm{CD}^{+} \mathrm{T}$ cells from the peripheral blood of RA patients respond to BiP stimulation and release cytokines such as interleukin (IL)-10 [22]. In inflammatory arthritis mouse models, the intravenous administration of $\mathrm{BiP}$ ameliorated joint inflammation, and the Th2 cytokine IL-
4 was associated with these anti-inflammatory effects [33]. Although some reports showed that BiP induces anti-inflammatory $\mathrm{T}$ cells that produce IL-4 and IL-10, pro-inflammatory responses to $\mathrm{BiP}$ were also observed. BiP-stimulated human peripheral blood mononuclear cells secreted tumor necrosis factor (TNF)- $\varepsilon$ in the early phase [34], and mouse BiP-primed T cells simultaneously produced interferon- $\gamma$ [33]. In fact, anti-BiP antibodies develop in RA patients, form immune complexes, and induce inflammatory processes in the synovium. Thus, the role of $\mathrm{BiP}$ in the pathogenesis of $\mathrm{RA}$ is controversial.

In the present study, we demonstrated that citBiP is a new target of RA autoantibodies and that the serum 


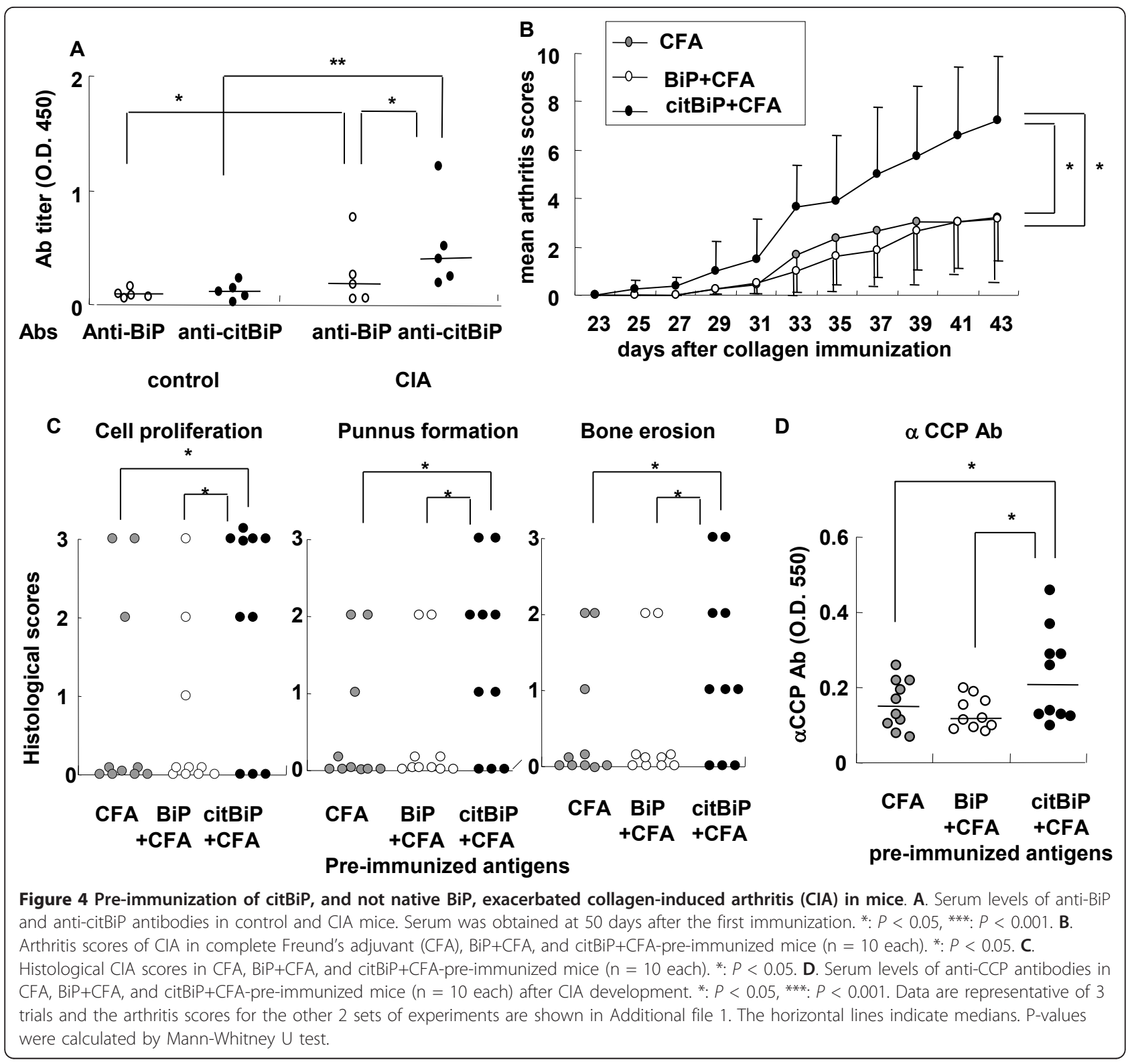

levels of anti-citBiP antibodies are higher in RA patients than those of anti-BiP antibodies. We performed B cell epitope mapping of BiP and citBiP. B cell epitope mapping using linear peptides sometimes misses discontinuous epitopes, which are recognized by antibodies only in the native conformation. Nevertheless, this protocol is good at identifying continuous epitopes, which are formed from single short peptide strands constructed on a generally linear backbone structure. In our study, the locations of the major epitopes of the anti-citBiP antibodies were clearly different from those of the anti-native BiP antibodies. Despite the limitation of using linear peptides for epitope mapping, these data suggested that the anti-citBiP and anti-BiP antibodies are produced via different processes in RA patients. In addition, there was no significant difference between the serum levels of anti-BiP and anti-citBiP antibodies in SLE patients, suggesting that the development of anti-citBiP antibodies was a distinct process in RA.

In the mouse model, citBiP immunization induced higher anti-CCP antibody levels than BiP immunization. Furthermore, citBiP pre-immunization exacerbated inflammatory arthritis, whereas BiP pre-immunization had no significant effects on CIA. Therefore, we believe that citBiP is more arthrogenic than $\mathrm{BiP}$ and could play an important role in the pathogenesis of inflammatory arthritis. In this context, the existence and localization of citBiP are important questions. Some reports have 
shown that $\mathrm{BiP}$ was overexpressed in the inflamed synovial tissues of RA patients [20,21]. Although citrullinated $\mathrm{BiP}$ was not detected in the synovial exosomes of RA patients [35], Lu et al. recently reported that citBiP was expressed on macrophage membranes, a target of ACPAs [36]. They also demonstrated that ACPAs could bind to citBiP on macrophage surfaces to induce the secretion of TNF- $\varepsilon$. Therefore, it is possible that macrophage membrane-bound citBiP is a source of the citrullinated protein in some situations.

The role of protein citrullination in the pathogenesis of RA has been widely investigated, and some reports explained the role of protein citrullination in the immune system. First, protein citrullination modifies the electric charge, i.e., arginine is positively charged, while citrulline is neutral. This electric change may result in a structural change of the protein and reveal hidden epitopes [37]. Other groups have reported that protein citrullination itself reinforced antigenicity and induced more intense immune responses. The citrullinated autoantigens possessed enough antigenicity to break immune tolerance to the auto-antigens $[18,38]$. In our data, citBiP immunization induced several kinds of ACPAs and exacerbated arthritis. We suppose that the pre-induction of anti-CCP antibodies could explain this pro-arthritis effect of citBiP immunization. However, the precise role of anti-CCP antibodies in mice remains unclear. Although more observations are necessary to demonstrate how the preceding immune responses to citBiP exacerbate CIA, these studies suggested the reason why the immune responses to citBiP were different from those to BiP in RA patients and our mouse model.

In the mouse study, we demonstrated that citBiPimmunization could induce several ACPAs. One possible explanation is epitope spreading. Epitope spreading has been demonstrated in a variety of spontaneous and induced autoimmune diseases, such as experimental autoimmune encephalitis and diabetes in NOD mice $[38,39]$. A recent study showed that epitope spreading of ACPAs was observed in RA patients [40]. In our mouse study, immunization with citBiP could induce antibody responses to other citrullinated proteins, such as citrullinated fibrinogen and filaggrin. The pivotal role of $B$ cells in epitope spreading has been proposed because $B$ cells are very efficient antigen-presenting cells or antigens that are taken up specifically through the B-cell receptor [41]. On the basis of the fact that different ACPA responses are cross-reactive [42], one hypothesis suggests that B cells expressing the B-cell receptor specific to citBiP could uptake and present several kinds of citrullinated proteins other than citBiP. The immune response to citBiP immunization could be a good model to study how the development of several ACPAs occurs, although more examinations are required.
With regard to the majority of target proteins for ACPA, including fibrinogen, vimentin, and alpha-enolase, antibodies react only with the citrullinated forms of these molecules and not with their native forms. In sharp contrast, antibodies to native BiP are readily detected in RA patients [20,21]. In this study, immunization with BiP also induced low anti-CCP antibody titers. Ireland et al. suggested that APCs could present citrullinated peptides even when given an unmodified protein [43], which could be an explanation for this phenomenon. Nonetheless, subcutaneous pre-immunization with $\mathrm{BiP}$ coupled with adjuvant induced no significant effects on CIA development in our experiments. These results suggest that an immune response to the native form of $\mathrm{BiP}$ is not sufficient for the progression of arthritis and that a significant level of immunity against citBiP is required. However, immunity to $\mathrm{BiP}$ and citBiP may augment the production of other ACPAs in RA.

\section{Conclusions}

In conclusion, we demonstrated that anti-citBiP antibodies appeared in the sera of RA patients. Because the serum levels of anti-citBiP antibodies were higher than those of anti-BiP antibodies in $72 \%$ of RA patients, and the location of the major epitopes of anti-citBiP and anti-BiP antibodies were different in RA patients, the development of anti-citBiP antibodies can be a distinct process in the pathogenesis of RA. In our mouse study, immunization with citBiP induced several kinds of ACPAs, including anti-CCP and anti-citrullinated fibrinogen antibodies. Furthermore, pre-immunization with citBiP exacerbated CIA. Therefore, we concluded that citBiP could play an important role in the pathogenesis of inflammatory arthritis and could be a new diagnostic and therapeutic target for RA.

\section{Additional material}

Additional file 1: The arthritis scores for the other 2 sets of trials in collagen-induced arthritis (CIA) mice that were pre-immunized with complete Freund's adjuvant (CFA), BiP+CFA, or citBiP+CFA ( $n=10$ each). ${ }^{*}: P<0.05$.

\section{Abbreviations}

ACPAs: anti-citrullinated protein/peptide antibodies; BiP: immunoglobulin binding protein; CCP: cyclic citrullinated peptide; CFA: complete Freund's adjuvant; CIA: collagen-induced arthritis; citBiP: citrullinated immunoglobulin binding protein; HRP: horseradish peroxidase; IFA: incomplete Freund's adjuvant; IL: interleukin; PADI: peptidyl arginine deiminase; RA: rheumatoid arthritis; RF: rheumatoid factor; SLE: systemic lupus erythematosus; TNF: tumor necrosis factor.

\section{Acknowledgements}

The authors are grateful to Ms Kazuko Inoue, Ms Kanako Sakashita, Ms Ayako Shibuya and Ms Kayako Watada for their excellent technical assistance. This study is supported by grants from the Ministry of Health, Labour and 
Walfare, Ministry of Education, Culture, Sports, Science and Technology (MEXT) and Japan Society for the Promotion of Science (including KAKENHI MEXT Grant-in-Aid for Young Scientists (B) (22790926)).

\section{Author details}

${ }^{1}$ Department of Allergy and Rheumatology, Graduate School of Medicine, the University of Tokyo, 7-3-1 Hongo, Bunkyo-ku, Tokyo, Japan. ${ }^{2}$ Department of Rheumatology, Tokyo Medical University, 6-7-1, Nishisinjyuku, Sinjuku-ku, Tokyo, Japan.

\section{Authors' contributions}

HS performed the majority of the experimental study and the statistical analysis, and prepared the manuscript. KF was involved in the design of the study, collecting the patients, and helped with drafting the manuscript. MS, $\mathrm{TO}, \mathrm{SS}, \mathrm{AO}, \mathrm{TS}$ assisted in conducting the experiments and collecting the patients. KY was involved in the design and conception of the study, and helped with drafting the manuscript. All authors read and approved the final manuscript.

\section{Competing interests}

The authors declare that they have no competing interests.

Received: 16 April 2011 Revised: 20 September 2011

Accepted: 22 November 2011 Published: 22 November 2011

\section{References}

1. Lipsky PE, van der Heijde DM, St Clair EW, Furst DE, Breedveld FC, Kalden JR, Smolen JS, Weisman M, emery P, Feldmann M, Harriman GR, Maini RN: Infliximab and methotrexate in the treatment of rheumatoid arthritis. Anti-Tumor Necrosis Factor Trial in Rheumatoid Arthritis with Concomitant Therapy Study Group. N Engl J Med 2000, 343:1594-1602.

2. Hueber W, Utz PJ, Robinson WH: Autoantibodies in early arthritis: advances in diagnosis and prognostication. Clin Exp Rheumatol 2003, 21 S59-64.

3. Girbal-Neuhauser E, Durieux JJ, Arnaud M, Dalbon P, Sebbag M, Vincent C, Simon M, Senshu T, Masson-Bessiere C, Jolivet-Reynaud C, Jolivet M, Serre G: The epitopes targeted by the rheumatoid arthritis-associated antifilaggrin autoantibodies are posttranslationally generated on various sites of (pro)filaggrin by deimination of arginine residues. $J$ Immunol 1999, 162:585-594

4. van Gaalen FA, Linn-Rasker SP, van Venrooij WJ, de Jong BA, Breedveld FC, Verweij CL, Toes RE, Huizinga TW: Autoantibodies to cyclic citrullinated peptides predict progression to rheumatoid arthritis in patients with undifferentiated arthritis: a prospective cohort study. Arthritis Rheum 2004, 50:709-715.

5. dos Anjos LM, Pereira IA, d'Orsi E, Seaman AP, Burlingame RW, Morato EF: A comparative study of IgG second- and third-generation anti-cyclic citrullinated peptide (CCP) ELISAs and their combination with IgA thirdgeneration CCP ELISA for the diagnosis of rheumatoid arthritis. Clin Rheumatol 2009, 28:153-158.

6. Damjanovska L, Thabet MM, Levarth EW, Stoeken-Rijsbergen G, van der Voort El, Toes RE, Huizinga TW, van der Helm-van Mil AH: Diagnostic value of anti-MCV antibodies in differentiating early inflammatory arthritis. Ann Rheum Dis, 69:730-732.

7. Nielen MM, van Schaardenburg D, Reesink HW, van de Stadt RJ, van der Horst-Bruinsma IE, de Koning MH, Habibuw MR, Vandenbroucke JP, Dijkmans BA: Specific autoantibodies precede the symptoms of rheumatoid arthritis: a study of serial measurements in blood donors. Arthritis Rheum 2004, 50:380-386.

8. Rantapaa-Dahlqvist S, de Jong BA, Berglin E, Hallmans G, Wadell G, Stenlund $H$, Sundin $U$, van Venrooij WJ: Antibodies against cyclic citrullinated peptide and $\lg A$ rheumatoid factor predict the development of rheumatoid arthritis. Arthritis Rheum 2003, 48:2741-2749.

9. Masson-Bessiere C, Sebbag M, Girbal-Neuhauser E, Nogueira L, Vincent C, Senshu T, Serre G: The major synovial targets of the rheumatoid arthritisspecific antifilaggrin autoantibodies are deiminated forms of the alphaand beta-chains of fibrin. J Immunol 2001, 166:4177-4184.

10. Tilleman K, Van Steendam K, Cantaert T, De Keyser F, Elewaut D, Deforce D: Synovial detection and autoantibody reactivity of processed citrullinated isoforms of vimentin in inflammatory arthritides. Rheumatology (Oxford) 2008, 47:597-604.
11. Uysal H, Bockermann R, Nandakumar KS, Sehnert B, Bajtner E, Engstrom A, Serre G, Burkhardt H, Thunnissen MM, Holmdahl R: Structure and pathogenicity of antibodies specific for citrullinated collagen type II in experimental arthritis. J Exp Med 2009, 206:449-462.

12. Kinloch A, Lundberg K, Wait R, Wegner N, Lim NH, Zendman AJ, Saxne T, Malmstrom $V$, Venables PJ: Synovial fluid is a site of citrullination of autoantigens in inflammatory arthritis. Arthritis Rheum 2008, 58:2287-2295.

13. Takizawa Y, Suzuki A, Sawada T, Ohsaka M, Inoue T, Yamada R, Yamamoto K: Citrullinated fibrinogen detected as a soluble citrullinated autoantigen in rheumatoid arthritis synovial fluids. Ann Rheum Dis 2006, 65:1013-1020.

14. Mahdi $H$, Fisher BA, Kallberg H, Plant D, Malmstrom V, Ronnelid J, Charles P, Ding B, Alfredsson L, Padyukov L, Symmons DP, Venables PJ, Klareskog L, Lundberg K: Specific interaction between genotype, smoking and autoimmunity to citrullinated alpha-enolase in the etiology of rheumatoid arthritis. Nat Genet 2009, 41:1319-1324.

15. Kuhn KA, Kulik L, Tomooka B, Braschler KJ, Arend WP, Robinson WH, Holers VM: Antibodies against citrullinated proteins enhance tissue injury in experimental autoimmune arthritis. J Clin Invest 2006, 116:961-973.

16. van Venrooij WJ, van Beers JJ, Pruijn GJ: Anti-CCP Antibody, a Marker for the Early Detection of Rheumatoid Arthritis. Ann N Y Acad Sci 2008, 1143:268-285.

17. Zhao X, Okeke NL, Sharpe O, Batliwalla FM, Lee AT, Ho PP, Tomooka BH, Gregersen PK, Robinson WH: Circulating immune complexes contain citrullinated fibrinogen in rheumatoid arthritis. Arthritis Res Ther 2008, 10: R94.

18. Hill JA, Bell DA, Brintnell W, Yue D, Wehrli B, Jevnikar AM, Lee DM, Hueber W, Robinson WH, Cairns E: Arthritis induced by posttranslationally modified (citrullinated) fibrinogen in DR4-IE transgenic mice. J Exp Med 2008, 205:967-979

19. Suzuki A, Yamada R, Chang X, Tokuhiro S, Sawada T, Suzuki M, Nagasaki M, Nakayama-Hamada M, Kawaida R, Ono M, Ohtsuki M, Furukawa H, Yoshino S, Yukioka M, Tohma S, matsubara T, Wakitani S, Teshima R, Nishioka Y, Sekine A, lida A, Takahashi A, Tsunoda T, Nakamura Y, Yamamoto K: Functional haplotypes of PADI4, encoding citrullinating enzyme peptidylarginine deiminase 4, are associated with rheumatoid arthritis. Nat Genet 2003, 34:395-402.

20. Blass S, Union A, Raymackers J, Schumann F, Ungethum U, MullerSteinbach S, De Keyser F, Engel JM, Burmester GR: The stress protein BiP is overexpressed and is a major $B$ and $T$ cell target in rheumatoid arthritis. Arthritis Rheum 2001, 44:761-771.

21. Corrigall VM, Bodman-Smith MD, Fife MS, Canas B, Myers LK, Wooley P, Soh C, Staines NA, Pappin DJ, Berlo SE, van Eden W, van Der Zee R, Lanchbury JS, Panayi GS: The human endoplasmic reticulum molecular chaperone $\mathrm{BiP}$ is an autoantigen for rheumatoid arthritis and prevents the induction of experimental arthritis. J Immunol 2001, 166:1492-1498.

22. Bodman-Smith MD, Corrigall VM, Kemeny DM, Panayi GS: BiP, a putative autoantigen in rheumatoid arthritis, stimulates IL-10-producing CD8positive T cells from normal individuals. Rheumatology (Oxford) 2003, 42:637-644.

23. Arnett FC, Edworthy SM, Bloch DA, McShane DJ, Fries JF, Cooper NS, Healey LA, Kaplan SR, Liang MH, Luthra HS, Medsger TA, Mitchell DM, Neustadt DH, Pinals RS, Schaller JG, Sharp JT, Wilder RL, Hunder GG: The American Rheumatism Association 1987 revised criteria for the classification of rheumatoid arthritis. Arthritis Rheum 1988, 31:315-324.

24. Aletaha D, Neogi T, Silman AJ, Funovits J, Felson DT, Bingham CO, Birnbaum NS, Burmester GR, Bykerk VP, Cohen MD, Combe B, Costenbader KH, Dougados M, Emery P, Ferraccioli G, Hazes JM, Hobbs K, Huizinga TW, Kavanaugh A, Kay J, Kvien TK, Laing T, Mease P, Menard HA, Moreland LW, Naden RL, Pincus T, Smolen JS, Stanislawska-Biernat E, Symmons D, et al: 2010 Rheumatoid arthritis classification criteria: an American College of Rheumatology/European League Against Rheumatism collaborative initiative. Arthritis Rheum 2010, 62:2569-2581.

25. Tan EM, Cohen AS, Fries JF, Masi At, McShane DJ, Rothfield NF, Schaller JG, Talal N, Winchester RJ: The 1982 revised criteria for the classification of systemic lupus erythematosus. Arthritis Rheum 1982, 25:1271-1277.

26. Hochberg MC: Updating the American College of rheumatology revised criteria for classification of systemic lupus erythematosus. Arthritis Rheum 1997, 40:1725.

27. Senshu T, Akiyama K, Kan S, Asaga H, Ishigami A, Manabe M: Detection of deiminated proteins in rat skin: probing with a monospecific antibody 
after modification of citrulline residues. J Invest Dermatol 1995, 105:163-169.

28. Courtenay JS, Dallman MJ, Dayan AD, Martin A, Mosedale B: Immunisation against heterologous type II collagen induces arthritis in mice. Nature 1980, 283:666-668.

29. Deng GM, Zheng L, Chan FK, Lenardo M: Amelioration of inflammatory arthritis by targeting the pre-ligand assembly domain of tumor necrosis factor receptors. Nat Med 2005, 11:1066-1072.

30. Taniguchi K, Kohsaka H, Inoue N, Terada Y, Ito H, Hirokawa K, Miyasaka N: Induction of the p16INK4a senescence gene as a new therapeutic strategy for the treatment of rheumatoid arthritis. Nat Med 1999, 5:760-767.

31. Weber CK, Haslback M, Englbrecht M, Sehnert B, Mielenz D, Graef D, Distler JH, Mueller RB, Burkhardt H, Schett G, Voll RE, Furnrohr BG: Antibodies to the endoplasmic reticulum-redident chaperons calnexin, BiP and Grp94 in patients with rheumatoid arthritis and systemic lupus erythematosus. Rheumatology 2010, 49:2255-2263.

32. Vossenaar ER, Nijenhuis $S$, Helsen MM, van der Heijden A, Senshu T, van den Berg WB, van Venrooji WJ, Joosten LA: Citrullination of synovial proteins in murine models of rheumatoid arthritis. Arthritis Rheum 2003, 48:2489-2500.

33. Brownlie RJ, Myers LK, Wooley PH, Corrigall VM, Bodman-Smith MD, Panayi GS, Thompson SJ: Treatment of murine collagen-induced arthritis by the stress protein BiP via interleukin-4-producing regulatory T cells: a novel function for an ancient protein. Arthritis Rheum 2006, 54:854-863.

34. Corrigall VM, Bodman-Smith MD, Brunst M, Cornell H, Panayi GS: Inhibition of antigen-presenting cell function and stimulation of human peripheral blood mononuclear cells to express an antiinflammatory cytokine profile by the stress protein BiP: relevance to the treatment of inflammatory arthritis. Arthritis Rheum 2004, 50:1164-1171.

35. Skriner $K$, Adolph $K$, Jungblut $P R$, Burmester GR: Association of citrullinated proteins with synovial exosomes. Arthritis Rheum 2006, 54:3809-3814.

36. Lu MC, Lai NS, Yu HC, Huang HB, Hsieh SC, Yu CL: Anti-citrullinated protein antibodies bind surface-expressed citrullinated Grp78 on monocyte/macrophages and stimulate tumor necrosis factor alpha production. Arthritis Rheum 2010, 62:1213-1223.

37. Gyorgy B, Toth E, Tarcsa E, Falus A, Buzas El: Citrullination: a posttranslational modification in health and disease. Int I Biochem Cell Biol 2006, 38:1662-1677.

38. Lundberg K, Nijenhuis S, Vossenaar ER, Palmblad K, van Venrooij WJ, Klareskog L, Zendman AJ, Harris HE: Citrullinated proteins have increased immunogenicity and arthritogenicity and their presence in arthritic joints correlates with disease severity. Arthritis Res Ther 2005, 7:R458-467.

39. Zechel MA, Krawetz MD, Singh B: epitope dominance: evidence for reciprocal determinatant spreading to glutamic acid decarboxylae in non-obese diabetic mice. Immunol rev 1998, 164:111-118.

40. van der Woude D, Rantapaa-Dahlqvist S, loan-Facsinay A, Onnekink C, Schwarte CM, Verpoort KN, Drijfhout JW, Huizinga TW, Toes RE, Pruijn GJ: Epitope spreading of the anti-citrullinated protein antibody response occurs before disease onset and its associated with the disease course of early arthritis. Ann Rheum Dis 2010, 69:1554-1561.

41. Shlomchik MJ, Craft JE, Mamula MJ: From T to B and back again: positive feedback in systemic autoimmune disease. Nat rev immunol 2001 1:147-153.

42. Ioan-Facsinay A, el-Bannoudi H, Scherer HU, van der Woude D, Menard HA, Lora M, Trouw LA, Huizinga TW, Toes RE: Anti-cyclic citrullinated peptide antibodies are a collection of anti-citrullinated protein antibodies and contain overlapping and non-overlapping reactivities. Ann Rheum Dis 2011, 70:188-193.

43. Ireland J, Herzog J, Unanue ER: Cutting edge: unique T cells that recognize citrullinated peptides are a feature of protein immunization. $J$ Immunol 2006, 177:1421-1425.

\section{doi:10.1186/ar3520}

Cite this article as: Shoda et al:: Detection of autoantibodies to citrullinated BiP in rheumatoid arthritis patients and pro-inflammatory role of citrullinated BiP in collagen-induced arthritis. Arthritis Research \& Therapy 2011 13:R191.

\section{Submit your next manuscript to BioMed Central and take full advantage of:}

- Convenient online submission

- Thorough peer review

- No space constraints or color figure charges

- Immediate publication on acceptance

- Inclusion in PubMed, CAS, Scopus and Google Scholar

- Research which is freely available for redistribution 